\title{
SERPINB9 Gene
}

National Cancer Institute

\section{Source}

National Cancer Institute. SERPINB9 Gene. NCI Thesaurus. Code C104578.

This gene plays a role in the regulation of granzyme B-mediated proteolysis. 